\section{Russia shifts stance on climate-change policy}

Russia's government has quietly made a dramatic change to its policy on climate change, accepting that anthropogenic global warming poses severe risks and requires immediate action to limit carbon emissions.

"Russia's diplomatic approach to [December's scheduled climate talks in] Copenhagen was until now just one big silence," says Kristin Jørgensen, a climate-policy expert with Bellona, an environmental watchdog based in Norway that has a network of activists in Russia. "This is a totally surprising move. There were no hearings, no stakeholder discussion, no public debate - just nothing."

Policy analysts believe that the new climate 'doctrine', adopted in late April, marks a historic turning point. Principally a position statement, the doctrine also outlines a checklist of key climate actions. It follows a February assessment report compiled by leading Russian climate scientists, which was presented to the Russian cabinet on 23 April. For a longer version of this story, see http://tinyurl.com/q2tyjn.

\section{United States urged to boost global health funds}

An expert committee convened by the US Institute of Medicine has called for the country to increase investment in global health initiatives to $\$ 15$ billion per year by 2012 .

Earlier in May President Barack Obama asked Congress to dedicate an average of $\$ 10.5$ billion per year over the next six years to a global health initiative, with $\$ 8.5$ billion of that funding dedicated to the HIV/AIDS programme PEPFAR (see Nature 457, 254-256; 2009).

But the committee, which included former National Institutes of Health head Harold Varmus, recommended that $\$ 13$ billion be invested in fulfilling healthrelated Millennium Development Goals put forward by the United Nations, with another $\$ 2$ billion for combating injuries and non-communicable conditions, such as heart disease. In addition, it advised that an inter-agency global health committee be created and located in the White House to coordinate such activities.

\section{JOHN MADDOX}

A memorial meeting to celebrate the life of Sir John Maddox, the editor of Nature for many years, will be held on Friday 5 June 2009 at 6 p.m., followed by a reception, at The Royal Institution, 21 Albemarle Street, London W1S 4BS.

Those wishing to attend should notify Diane Kempinski at Nature, d.kempinski@nature.com. Places are limited.

\title{
THAT FOSSIL FRENZY IN FULL
}

"This specimen is like finding the lost ark for archaeologists. It is the scientific equivalent of the Holy Grail."

Jørn Hurum, University of Oslo, at the New York press unveiling of a 47-million-year-old fossil, christened Ida (pictured), last week.

\section{"[It is] like the eighth wonder of the world."}

Jens Franzen, Natural History Museum of Basel, Switzerland, who was involved in analysing the fossil.

"Any pop band is doing the same thing. We have to start thinking the same way in science."

Hurum justifies the attention.

"There was a TV company involved and time pressure. We've been pushed to finish the study; it's not how I like to do science."

Hurum's co-worker Philip Gingerich of the University of Michigan, Ann Arbor, reflects.

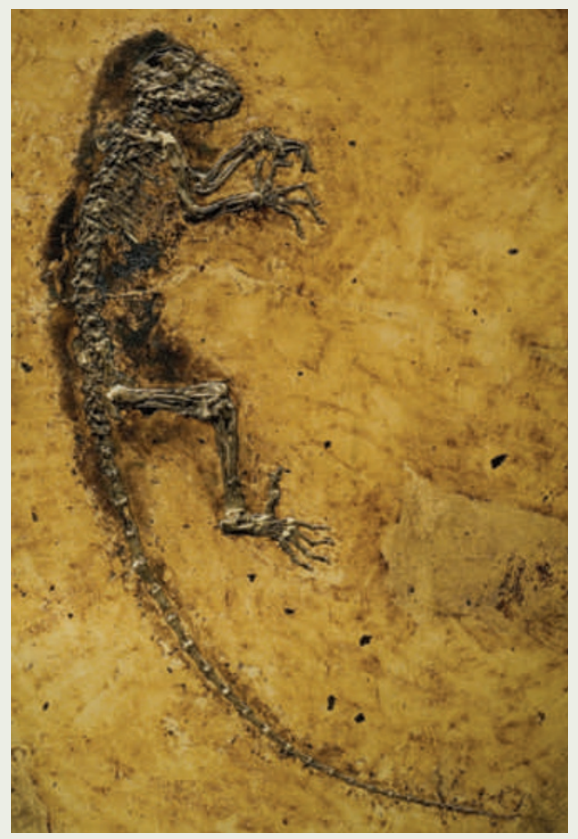

For more on Ida see http://tinyurl.com/idafossil and Editorial, page 484.

Sources: The Wall Street Journal, The New York Times, BBC, Fox News, The Guardian

\section{UK geographers vote against large expeditions}

Members of London's Royal Geographical Society have thrown out a resolution to resume large exploratory expeditions. Campaigners say that the vote highlights growing division within the world's biggest scholarly geographical society.

The society stopped organizing large expeditions such as open-ended explorations of rainforests, after reviews of research practices in 2001 and 2004 suggested that smaller, more focused projects were the best ways to tackle global problems such as climate change and the security of food and water. "Twenty-firstcentury geography, not nineteenth-century geography, is what we're talking about," says Gordon Conway, the society's president.

The resolution was defeated by 2,590 votes to 1,607 on 18 May. Supporters of the 'Beagle Campaign' that put forward the resolution say they will continue to advocate their cause. For a longer version of this story, see http://tinyurl.com/pbx929.

\section{Delays to satellite launches put GPS at risk}

Concern over the future performance of the US Global Positioning System (GPS) went up a notch last week as a government watchdog official warned that the US Department of Defense faced substantial challenges meeting its space-programme commitments.
A report from the Government Accountability Office (GAO) on 30 April had cautioned that new GPS satellites might not be launched in time to replace the ageing constellation that is currently in orbit. And on 20 May, Cristina Chaplain, GAO director of acquisition and sourcing, told the Senate committee on armed services that cost overruns of space programmes are part of the problem.

Dave Buckman, of the US Air Force Space Command, quickly replied on a Twitter feed that "GPS isn't falling out of the sky". Still, a temporary decline in performance might cause a problem for scientists who rely on GPS-positioned equipment that cannot be easily upgraded, such as low Earth-orbiting satellites, says Marek Ziebart, a space geodesy researcher at University College London.

For a longer version of this story, see http://tinyurl.com/gpsthreat.

\section{Corrections}

The News Feature 'The sleeping dragon' (Nature 459, 153-157; 2009) misstated the number of landslides thought to result from the 2008 Sichuan earthquake. It should have said that scientists have identified at least 15,000 resulting landslides and rock avalanches, and perhaps as many as 50,000 or more.

The News story 'Even big societies feel the pinch' (Nature 459, 17; 2009) cited incorrect information, provided by the American Chemical Society, that the society had already posted a \$36.5-million bond in a lawsuit it recently lost. The society expects the bond will be posted by the first week of June. 